\title{
The Hidden Agendas of Common Security
}

\author{
Ferenc Miszlivetz
}

\section{Security and the Status Quo}

Global militarisation and its fetishisation as a naturally given phenomenon, follow from the present structure of world-wide inequality. The entrenchment of military and paramilitary institutions and the monopolisation of information through the mass media reproduce and increase subordination, exploitation and oppression between and within societies. The existing international status quo is nothing but a legal petrification of this situation. In theory it represents the interest of every nation-state, based on the idea that each state possesses equal rights. In reality the concept of security has been extended over and imposed on weaker states by their stronger fellows. 'If states are equal', they seem to be saying to their smaller allies or would-be allies, 'you have the choice to be protected by me, so my security will be your security'.

In the course of struggle for world hegemony, in which, in fact, only very few states have real chances, the question of maintaining the status quo is of crucial importance. Even if I cannot win at this very moment, I cannot concede acquired positions or lose my allies. From this point of view the concept of security subsumes the concept of power struggle.

Although in the era of nuclear technology this rivalry creates dangers for the superpowers themselves, their strategists and statesmen still cling to the theoretical possibility of some kind of victory. The irrational and anti-human nature of this hope is often pointed out. Yet it has never been entirely abandoned. Every power struggle, every effort to annihilate or paralyse the 'enemy' eo ipso involves this moment of irrationality. In this epoch of incredibly efficient technology, mankind is unable to exercise this irrationality or to curb it with a truly democratic control - either on a global level or through the nation-state.

The official ideologies which have successfully transplanted the concept of security into public opinion, are worth closer investigation. However obvious their contradictions, their efficiency is undeniable. The ideology of state socialism on one side, and of democracy and freedom on the other; the ideology of bureaucratic nationalism which interpenetrates with both of them; the ideology of national security, which is based upon bureaucratic nationalism; and the ideology of bloc-identity which combines bureaucratic nationalism with belief in world power hegemony - all these share a common element. They treat the squandering of scarce resources, the uncontrollable arms race, military institutions and the growing probability of a total nuclear confrontation as a natural and unquestioned feature of the world political scene.

It is almost as if the leaders of the military industrial complexes and military alliances have borrowed a lesson from Orwell and Marcuse. Except among a thin stratum of critical opinion, the anti-war propaganda of the war-preparing states causes apathy and indifference. Peace slogans are followed up by selfconfident parades of forces or by direct and indirect intimidation. So the concepts of war and peace are not only closely related to each other, but they merge into one dimension within which the threat of war from the one side legitimises armament of the other justifying the created image of danger and hence the stabilisation of internal order, in other words, the oppression of any dissent. Thus the social movements which give expression to economic or political tensions are portrayed as the 'agents' or 'vanguard' of the enemy and public opinion grows more and more apathetic.

\section{The New International Military Order - and Global Anarchy}

In the literature on the arms race and the New Cold War, more and more discussion can be found of their connection with the inner structure of the increasingly militaristic state and that of civil society subordinated to it. As a consequence efforts have been made to 
reconceptualise well-used political and politicalscientific concepts. In his essay on the new military order, for example, Jan Oberg argues that the war machine tends to penetrate ever more deeply into contemporary social formations [Oberg 1980]. The new International Military Order has been generated by the core industrial states and above all by the superpowers, bringing into existence global strategies, alliance systems, military infrastructures, the militarisation of space, etc. Even if they no longer fight wars amongst each other, the core-states shape global militarisation by creating and maintaining conflictcentres in underdeveloped societies into which they introduce the highly advanced technology derived from their arms production. This kind of 'development' combines both military and civil interests; and therefore there has emerged, he argues, an isomorphism between the civil and the military sphere of society: "Ismorphism suggests a fundamental, continuous correspondence between the two "spheres" of society. In principle, the notion applies both to the national and the international level of analysis' [Oberg 1980: 54].

Another way of putting it is that an isomorphism exists between modes of production and modes of destruction. This idea, the theoretical roots of which can be found in the late 19th century and early 20 th century Marxist literature - for example in the writings of Engels, Liebknecht, Luxemburg and Bukharin - has been further developed by Mary Kaldor with some criticism:

In the rare instances where Marxists have written about the mode of warfare, they have tended to assume that modes of warfare 'reflect' modes of production .. The point is not that modes of warfare 'reflect' modes of production but rather that warfare can only be produced on the basis of a given mode of production. The mode of warfare can never exactly reflect the mode of production because of its essentially parasitical nature, and because war as a form of commensuration differs from all other forms of commensuration [Kaldor 1982: 268-9].

The militarisation of civil society is a historical process, within which the emergence of total war proved to be a decisive step. This step became possible - and even necessary - on the base of technological development. This deepening gap between highly advanced technology and the failure to use it for democratic social purposes has created a deep civilisational crisis [see Miszlivetz and Kaldor 1985: 56-61]. The latter had already begun to manifest itself as early as World War I. As Abrahamsson [1972: 23] has put it: ". . the invention of the aeroplane and, later, the ballistic missile created a new concept - total warfare. Total warfare brought total defence; this, in turn, meant closer integration between the military and civilian sectors'.

But this integration is increasingly asymmetric, with the military-industrial sector tending to become the 'centre' while the civilian sector becomes peripheralised. Oberg [1980: 64] points out the interdependent nature of this process:

... as long as the civilian society is willing to pay for its own subordination, i.e. as long as it is politically accepted that the military sphere exploits ever larger civil resources in order to deliver a product called security, while civil society is rapidly losing every kind of inner strength and non-military defence capacity.

Hence this isomorphism involves the destruction of democratic values. The war machine and the military industrial complex have become organic in the economies and social formations of industrialised countries to such a degree that demilitarisation would (if not carefully managed) lead to the breakdown of political and social life.

This asymmetric integration of the military order within the boundaries of the nation-state also fosters subordination and insecurity on a global level. The efforts of the major powers to establish international security in the interstate system, only result in more anarchy and violence. Modifying Marx's phrase on capitalist development, according to which 'the road to Hell is paved with good intentions' we can say: the road leading to extermination is paved with disarmament negotiations.

One 'logical' resolution of this situation would be if one of the superpowers could establish a monopoly of military force on a global level, as has already happened on the 'national' and 'bloc' levels. But so far, all efforts to establish a lasting and exclusive world hegemony have failed. No state or military alliance has won a permanent and absolute victory in a 20 th century war. Thus the end of each war has become the starting point for new power struggles.

Another more likely outcome of the present situation is the conservation of existing political, economic and cultural tensions in the form of more than one world empire - a new step towards the world of 1984. The bipolar cold war logic seems to strengthen this possibility. Tacit mutual agreement amongst the world powers stipulates that none of them will use nuclear weapons. Meanwhile wars are fought by 'conventional' means in 'peripheral' territories, keeping alive the need for 'security', 'order' and 'discipline' and the whole complex value system of civil subordination. 
Following Robin Luckham (1984) the present global scene can be described as an international anarchy, the final form of which is nuclear war. Luckham's analysis concludes that insecurity and irrationally are built into the premises of the arms race themselves. According to official ideologies, weapons systems defend the existing social and economic structures, together with the international division of labour which supports them. Yet the fact is that the question of how much force is needed for this 'defence' is entirely unanswerable. One may add that armament is motivated not only by the defence of the status quo, but also by struggles for world hegemony. Naturally, these struggles bear closely upon the international division of labour, upon the problem of resources and upon economic development/underdevelopment, and cannot be understood in isolation.

We have also to take into account other more neglected aspects of this anarchy, whose nature is less 'material'. One of these is the subordination of the institutions of international law and arbitration to the logic of bipolarity. Indeed, the monopoly of organised force may even be stronger at an international than at a 'national' level. At the same time, oversecured state boundaries mean that there is very little room for the internationalisation of democratic public opinion.

To summarise, the backwardness and provincialisation of the nation-state as a form of political organisation, relative to highly advanced and internationalised technology, help to explain the growing irrationalism of the arms race. In 1930 Walter Benjamin had already pointed out that 'every new war will be a slave revolt of technology' [Benjamin 1930]. Our problem is that this irrationalism presents itself in an apparently rational form. Even after two world wars and the nuclear arms race it is still capable of justifying itself according to Clausewitz's maxim that 'war is the continuation of politics but with different means'. I am not the first person to have argued that nuclear war is not the continuation but the end of politics.

This is only another aspect of the socioeconomic process we have described above: the subordination of modes of production by modes of destruction. To be more accurate: production in general is increasingly becoming the reproduction - on an increasing scale - of the means of destruction, manipulation and deterrence. The arms race threatens civil society with total occupation through its promiscuous network of military interests and the alliances organised around them.

\section{Militarisation in the South}

The concept of a new military order, however, does not mean that the process of global militarisation has evolved in the same form in all nation-states, or that we could speak of a homogenous militarism. A military monoculture exists only to the extent that military intervention and transfers of military technology by the centre-states of the North directly and indirectly structure militarisation in the periphery, creating new chains of dependence. Noam Chomsky in a recent essay emphasises the decisive role of superpowers in generating global militarisation:

Today, more than ever, a growing volume of military strategy and technology is designed by the superpowers not for war against each other, but for war against the weak, the defenceless people in underdeveloped countries who cannot strike back. This involves among other things helicopters, napalm, rapid deployment forces, and tactical nuclear weapons. These are not designed for wars against powerful nations.

In the post-war period, when the Third World countries started to struggle for their political independence, they had to confront this highly advanced technology. Under these circumstances there seemed little choice. They had to accept military aid and absorb modern weapon systems if they wanted to improve their position in the hierarchy of the interstate system. Thus their arms imports and military spending remained on a steady upward trend, which did not level off until the developing countries were hit by recession in the early 1980s.

However, it is impossible to understand the process of militarisation without also taking into account the 'inner' conditions of Third World societies. In the same way as the problems of underdevelopment are not merely economic, the process of militarisation, taking place under the circumstances of underdevelopment, necessarily includes political, ideological, cultural and socio-psychological elements. The danger lies in the possibility that militarisation - often launched with promises of 'development' and 'modernisation' - may become an organising force which will leave its mark on the process of development for ever.

This is all the more likely since Third World societies, though heterogenous, share certain common structural features. One of these is the lack of autonomous or democratic institutions or even the chance to establish them. Civil society is even weaker, and the practice of direct military repression is more familiar than in the countries of the industrialised North. Armies in the Third World thus tend to resemble superpolice, organised to combat inner not external 'enemies'.

Hence one faces a specific intertwining of modernisation and militarisation: the more underdeveloped an economic social formation, the more brutal and 
militaristic the process of modernisation tends to be; and the greater the contradiction between imported, highly advanced military technologies and the general state of society and economy. The build-up of military and paramilitary forces strengthens the already strong apparatuses of of ficial violence, widening the political role played by the military, extracting more and more from the otherwise scarce resources of poor countries.

What we get here is a peculiar contribution by the North to the 'rise of the South'. Imported means of destruction represent the most advanced output of industrial civilisation. These technical miracles contrast sharply with the material culture, technological level, and the adaptive ability of the societies and economies of the South. Even if imported military technologies and the infrastructures required for them can sometimes contribute to industrialisation, such a 'development' is almost invariably distorted.

\section{Realpolitik and Categorical Imperatives}

The concepts used by practising politicians necessarily fit within the intellectual framework of the status quo. The rules of the international political game - even when they concern 'neutral' international agencies confine official discourse to desires and categorical imperatives. Thus, when speaking of disarmament and the risks of war, they use phrases like 'states have to understand' or 'confidence has to be strengthened', etc.

Johan Galtung and other critics of the Palme Report have warned us that the Report cannot by itself mobilise opinion against the arms race and the nuclear threat [Galtung 1983]. The Palme Commission did not sufficiently explore the roots of and remedies for power struggles, growing official violence and international anarchy. The confidence it places in negotiations and treaties seems almost boundless, even when (as is mostly the case) they do not bring any tangible results.

Herbert Marcuse has called attention to the apologetic character of the 'applied sciences', which is based on nothing but the realism of 'this is the situation' [Marcuse 1964]. The philosophy of the Palme Commission follows a similar logic: 'Nobody is fond of war, we also denounce it. But there have always been wars. Money should be spent on other purposes, but until this is more generally recognised, we should concentrate on more limited arms control measures and strengthen the existing mechanisms of the United Nations'.

What is in question is not the intentions of the authors of the Report - who share an evident personal personal concern for peace - but their role as active statesmen. As such, they are or have been part of the global political system which has produced the arms race, deterrence and the militarisation of the South. Their status quo-supporting behaviour is also reflected in the fact that the authors of the Report neither express support for the European peace movements, nor hint that there might be common ground with other antisystemic movements such as the feminists, or the Greens. Nor do they show much interest in grassroots or liberation movements in the Third World.

In the recent past, the East-West balance, arms control and the multilateral approach to disarmament, have functioned as ideologies, legitimising the bipolar worldview and the security concept which sustains it. The Palme Report has not succeeded in transcending this rhetoric, so it can neither be translated into concrete political programmes nor be made a starting point for demilitarisation. Common security remains no more than an idea under the present circumstances of insecurity and mutual escalation in the arms race.

\section{References}

Abrahamson, Bengt, 1972, Military Professionalisation and Political Power, Sage, Beverly Hills

Benjamin, Walter, 1930, 'Theorien des deutschen Faschismus', in Die Gesellschaft: Internationale Revue für Socialismus und Politik nr 7 vol 2

Chomsky, Noam, 1982, 'Strategic arms, the Cold War and the Third World', in E. Thompson et al, Exterminism and Cold War, Verso, London

Galtung, Johan, 1983, 'The Palme Commission Report on Disarmament and Security. A Critical Comment', Bulletin of Peace Proposals, vol 14 no 2

Kaldor, Mary, 1982, 'Warfare and capitalism', in E. Thomson et al, Exterminism and Cold War, Verso, London

Luckham, Robin, 1984, 'The arms race and the New International Anarchy', Third World Quarterly, vol 6no 2, April

Marcuse, Herbert, 1964, One Dimensional Man, Routledge and Kegan Paul, London

Miszlivetz, Ferenc, and Mary Kaldor, 1985, 'Civilisational Crisis', in 'Slowdown or Crisis? Restructuring in the 1980s', IDS Bulletin vol 16 no 1, pp 56-61

Oberg, Jan, 1980. 'The New International Military Order: a Threat to Human Security', in Asbjorn Eide and Marek Thee (eds), Problems of Contemporary Militarism, Croom Helm, London 